\title{
The Utilization Implementation of High Sea According to Sea Convention Law of 1982
}

\author{
Ong Argo Victoria ${ }^{*}$ and Saleh Raed Shatat ${ }^{* *}$ \\ *) International Islamic University Malaysia, Email: argovictoriaupin@gmail.com \\ ${ }^{* *}$ University of Jordan, Email: salehshatat@gmail.com
}

\begin{abstract}
The purpose of this research is to find out how the implementation of the use of forms of freedom on the high seas according to the 1982 Law of the Sea Convention (UNCLOS 1982) and how the exceptions to freedom on the high seas according to the 1982 Law of the Sea Convention (UNCLOS 1982). The research method used in this research is using normative legal research methods and it can be concluded that the regulation regarding the high seas is contained in Part VII Article 86 to Article 120 of the 1982 Sea Law Convention to take advantage of the high seas. State freedoms on the high seas are freedoms in accordance with article 87, namely freedom of navigation, flight, laying submarine cables and pipelines, freedom to build artificial islands and other installations, freedom to fish, and freedom to conduct scientific research. Every given freedom can be used by every country but every country is obliged to maintain and utilize the high seas for peaceful purposes for the survival of human life. In addition to providing freedom to use the high seas, the 1982 Law of the Sea Convention provides exceptions to this freedom. Where every country is free to use the high seas but is not allowed to take illegal actions or violate the law, both national law and international law, which in its application are often violated by countries in the world. There are several exceptions to the freedom of the high seas such as the prohibition of slavery, piracy, trafficking in narcotic drugs and psychotropic substances, instant pursuit, illicit broadcasting, and pollution of the marine environment. So every country, both coastal and non-coastal countries, is required to cooperate in eradicating all forms of abuse of freedom on the high seas.

Keywords: Authority; Convention; Law; Maritime; Policy; Sea; Ship.
\end{abstract}

\section{Introduction}

The large number of sea areas that become state boundaries with other countries, the regulation of the width of the sea area is important and efforts to determine the width of a country's sea area have been started since the 19th century. This shows that the dynamics of states' desire for sovereignty in the sea area have been going on for a long time and this has followed the development of the United Nations Convention On The Law Of The Sea from UNCLOS I in 1958, UNCLOS II in 1960 to UNCLOS III in 1982 ${ }^{1}$.

\footnotetext{
${ }^{1}$ United Nations. Division for Ocean Affairs and the Law of the Sea. The Law of the Sea: multilateral treaties: a reference guide to multilateral treaties and other international instruments related to the United Nations Conventions on the Law of the Sea (revised and updated as of 31 December 1996). Edition: Law of the sea/Maritime law -- Indexes (United Nations publication sales no. E.85.V.12 [i.e. E.85.V.11])"-P. x. "United Nations publication sales no. E.97.V.9"--T.p. verso. Publisher New York: United Nations, 1997, Format: xiii, 184 p. ; 28 cm., ISBN : 9211335213 (pbk.)
} 
Based on the 1982 United Nations Convention on the Law of the Sea (UNCLOS) there are eight laws of the sea, namely²:

- Inland waters (internal waters),

- Archiplegic waters,

- Territorial sea (territorial waters);

- Additional zones (contingous waters);

- Exclusive economic zone

- Continental shelf;

- The high seas; and

- The international sea-bed area.

One that is discussed in the 1982 Law of the Sea Convention is the high seas. The high seas are parts of the sea that are not included in the exclusive economic zone, territorial sea or inland waters of archipelagic countries. ${ }^{3}$.

It is very clear that the high seas are sea areas that are not the territorial territory of a country. The sea which is not the territorial area of any country, the high seas are free seas or known as res nullius, where the sea is an area of waters that is not owned by anyone, which means that the high seas can be utilized by every country, both coastal and non-coastal countries. But the use of the high seas is only for peaceful purposes and no country may claim that part of the high seas as its own is under its sovereignty. Law on the high seas is regulated in the 1982 Law of the Sea Convention part VII articles 86 to $120^{4}$.

According to the 1982 Law of the Sea Convention part VII article 87, freedom on the high seas includes 5 :

- Freedom of sailing;

- Freedom of flight;

- Freedom to lay submarine cables and pipelines;

- Freedom to build artificial islands and other installations permitted under international law;

- Freedom to fish;

- Freedom of scientific research. Indonesia itself has ratified ${ }^{6}$

1982 Law of the Sea Convention with Act No. 17 of 1985 about. The ratification of the 1982 Law of the Sea Convention also contains several laws that specifically regulate parts of the sea and the use of the sea such as Act No. 31 of 2004 on Fisheries, Government Regulation no. 60 of 2007 concerning Conservation of Fish Resources, Government Regulation no. 17 of 1974 concerning Supervision of the Implementation of Oil and Gas Exploration and Exploitation in offshore areas, Act No. 4 of 1960 which

\footnotetext{
2 Shatat Saleh Raed Shatat. INTERNATIONAL LAW INTERNATIONS AND HUMAN RIGHTS. Vol 6, No 2 (2019) > http://lppm-unissula.com/jurnal.unissula.ac.id/index.php/PH/article/view/274-284

${ }^{3}$ The Law of the Sea: A Select Bibliography: Call Number: JX 4411 L418

${ }^{4}$ Marine Affairs Bibliography: A Comprehensive Index to Marine Law and Policy Literature: Call Number: JX 4411 W66

${ }^{5}$ Admiralty and Maritime Law Bibliography: Access to the Sea: LibGuide from the University of Richmond Law Library

${ }^{6}$ Hartanto, H.; Victoria, O.A.; Chuasanga, A. Maritime Transportation in Indonesian Policy. J. Pembaharuan Huk. 2019, 6, 36-44, Jurnal Pembaharuan Hukum Unissula, Vol. 6, No. 1 (2019), http://jurnal.unissula.ac.id/index.php/PH/article/view/4657
} 
has been replaced by Act No. 6 of 1996 concerning Indonesian Waters, Act No. 1 of 1973 concerning the Continental Shelf, Act No. 5 of 1983 concerning the Exclusive Economic Zone, as well as other related laws ${ }^{7}$.

Freedom on the high seas can be exercised by complying with the conditions provided by the 1982 Law of the Sea Convention and the conditions provided by International Law. With this freedom granted, the state has the advantage of being able to take advantage of this high seas area for the benefit of its country without harming other countries or other parties.

However, apart from having the right to utilize the high seas area, the state is also bound by its obligation not to take any action that could harm other parties or any action that could damage the high seas area itself. Every country is indeed given the freedom to use the high seas but the freedom that is given is not freedom without limits and without rules. The freedom to use the high seas is regulated in the 1982 Law of the Sea Convention and has terms and conditions that must be carried out, so that there are several exceptions to freedom in the high seas that absolutely must not be carried out on the high seas. Exceptions to freedom on the high seas include piracy, hot pursuit, fishing and pollution on the high seas ${ }^{8}$.

\section{Research Methods}

The research method used in the context of collecting data and materials for writing this thesis is a normative legal research method. Normative legal research is library law research. This research method is used in accordance with the main issues to be discussed, namely the implementation of the use of the high seas according to the 1982 Law of the Sea Convention?.

\section{Results and Discussion}

\subsection{Implementation of the Use of Freedom on the High Seas}

The freedom given to countries is the freedom to use the high seas with the aim of common interests to support the survival of mankind. In this section, we will discuss the regulation of the use of the high seas itself. The regulation regarding the high seas is contained in Part VII Articles 86 to 120 of the 1982 Sea Law Convention. In article 87 of the 1982 Sea Law Convention there are seven forms of freedom on the high seas and will be discussed one by one in this section. First, every State, whether coastal or landlocked, has the right to sail ships flying its flag on the high seas ${ }^{10}$.

Considering that this part of the earth consists of land that is separated by a stretch of sea, shipping in the sea is very necessary to meet the needs of life, especially as a means

\footnotetext{
${ }^{7}$ Elsevier's Maritime Dictionary in Three Languages, English, French, and Arabic: Call Number: KB 146 B16

${ }^{8}$ Marine Encyclopaedic Dictionary by Eric Sullivan: Call Number: KB 148 .S22 S94 1999

9 Transports maritimes: termes techniques, juridiques, et commerciaux: lexique anglais-français: Call Number: K 13.F8 T77

${ }^{10}$ Anirut Chuasanga, Ong Argo Victoria. ISM-CODE AS A LEGAL PROTECTION OF USE SHIPS ARE NOT CONFORT WITH MARINE STANDARD IN INDONESIA. Vol 8, No 1 (2021) > http:///ppmunissula.com/jurnal.unissula.ac.id/index.php/PH/article/view/15265
} 
of transportation and with the freedom to use the high seas for sailing, the state is given convenience and benefits who are on board the ship.

The flag state of the ship must pay attention to the provisions of article 91 regarding the conditions for sailing on the high seas regarding the nationality of the ship, registration or registration and the flag of the ship there is a genuine link between the ship and the country concerned.

The second freedom is the freedom of overflight or the freedom of flight. All countries, both coastal and non-coastal countries, have the freedom to fly in the air space over the high seas, of course, by taking into account the interests of other countries. This freedom is not discussed in more detail in the articles of the 1982 Law of the Sea Convention.

However, based on article 87 paragraphs 1 and 2 of the 1982 Sea Law Convention, every country, both coastal and non-coastal countries, can use the high seas for flight, meaning that aircraft from each country can fly and pass freely over the high seas.

In essence, the same as other forms of freedom granted by the 1982 Law of the Sea Convention, flights over the high seas must be carried out with due regard to the terms and conditions both in the 1982 Law of the Sea Convention and other international law provisions. Also flights over the high seas are only carried out for peaceful purposes by taking into account the interests of other countries without harming them ${ }^{11}$.

The third freedom is that all States are entitled to lay submarine cables and pipelines on the bed of the high seas beyond the continental shelf. Regarding this freedom, it is regulated in articles 87, 112 to 115 of the 1982 Law of the Sea Convention. Every country has the right to install submarine cables or pipelines with due observance of the provisions in the 1982 law of the sea convention relating to the continental shelf, namely article 79 paragraph 5.

The fourth freedom according to article 87 of the 1982 sea law convention is freedom to construct artificial islands and other installations permitted under international law, subject to Part VI. Every country, both coastal and non-coastal countries, has the freedom to create artificial islands or other installations on the high seas subject to part VI of the 1982 law of the sea convention. Part VI of this 1982 Law of the Sea Convention is part of the continental shelf and according to article 80: "Article 60 applies mutatis mutandis to artificial islands, installations and structures on the continental shelf. ${ }^{12 "}$

So the provisions regarding artificial islands and other installations apply mutatis mutandis with the provisions contained in article 60, namely: Artificial islands, installations and structures do not possess the status of islands. They have no territorial sea of their own, and their presence does not affect the delimitation of the territorial sea, the exclusive economic zone or the continental shelf. This means that artificial islands, installations and buildings do not have island status. Artificial islands, installations and structures do not have their own territorial sea, and their presence does not affect the delimitation of the territorial sea, exclusive economic zone or continental shelf. The provisions in this article are very clear regarding the status of

\footnotetext{
${ }^{11}$ Buchari, E., \& Victoria, A. (2021). Policies Conducted to Support Maritime Safety and Security in Sea Transportation Systems. KnE Social Sciences, 5(1), 238-248. https://doi.org/10.18502/kss.v5i1.8286

12 Paulina M. Latuheru, Miko Priambudi \& Ong Argo Victoria. Responsibility of Sea Transportation Services. VOL 2 NO 1 (2020): INTERNATIONAL WATER TRANSPORT JOURNAL (IWTJ: OCTOBER) / Articleshttp://ejournal.poltektranssdp-palembang.ac.id/index.php/IWTJ/article/view/84
} 
artificial islands and other installations. The fifth freedom is the freedom of fishing or the freedom to catch fish.

Based on the convention, every country, both coastal and non-coastal, can take advantage of freedom on the high seas in the form of freedom to catch fish by taking into account the existing terms and conditions while also maintaining the high seas environment itself. Article 116 of the 1982 Law of the Sea Convention gives a state the right to send its national fishing fleet to the high seas. 8 In the article it is stated: "All States have the right for their nationals to engage in fishing on the high seas subject to: (a) their treaty obligations ; (b) the rights and duties as well as the interests of coastal States provided for, inter alia, in article 63, paragraph 2, and articles 64 to 67; and (c) the provisions of this section. "All States have the right for their nationals to fish on the high seas subject to: (a) their obligations under international agreements; (b) the rights and obligations as well as the interests of the coastal State, which are determined, inter alia, in article 63, paragraph 2, and articles 64 to 67; and (c) the provisions of this section.

\subsection{Exceptions to the Principle of Freedom on the High Seas}

But for these forms of freedom on the high seas there are exceptions, namely there are things that should not be done on the high seas even though the high seas are open seas and the state has the freedom to take advantage of the high seas. -actions that are against the law and are not a peaceful cause for the benefit of mankind. There are several things that are not allowed to be done on the high seas, namely:

- Slavery

- Piracy

- Trafficking of narcotic drugs or psychotropic substances

- Dark broadcast

- Instant chase (Hot persuit)

- Environmental pollution

Every human being has the right to be free from slavery, this is regulated in national law and international law. The right to be free from slavery is stated in the Universal Declaration of Human Rights 1948 and in Indonesia itself the right of everyone not to be enslaved is contained in the state constitution, namely Article 28 I paragraph 1 of the 1945 Constitution. With the existence of national and international regulations that prohibit slavery this proves that the act of slavery is prohibited and opposed by all countries. After slavery the second exception is piracy. The prohibition of piracy on the high seas is regulated in Articles 100 to 107 of the 1982 Law of the Sea Convention ${ }^{13}$. The discussion on piracy on the high seas is a discussion that gets great attention in the 1982 Law of the Sea Convention, because piracy is regulated in several articles, namely from Article 100 to Article 107 while other actions are only regulated in one article. In addition, the procedure for enforcing the law of the sea against the crime of piracy as regulated in Article 105 of the Convention turns out to be very clear and firm compared to the crime of slavery and narcotics.

\footnotetext{
${ }^{13}$ Junyu, M., Victoria, O. A., \& Arifani, D. (2021). Sea Transportation System Policy. KnE Social Sciences, 5(1), 147-157. https://doi.org/10.18502/kss.v5i1.8277
} 
The third exception to freedom on the high seas is the exception to the trade in narcotic drugs and psychotropic substances. Trafficking in narcotic drugs and psychotropic substances is an illegal trade which is included in acts against the law not only in Indonesia but in all parts of the world. Therefore, every country is invited to work together to suppress the trade in narcotic drugs and psychotropic substances on the high seas. The prohibition on the trade in narcotic drugs and psychotropic substances is not discussed in detail and unequivocally like the discussion on piracy in the 1982 Law of the Sea Convention.

However, although it is not discussed at length, the prohibition against trafficking in narcotic drugs and psychotropic substances is clearly opposed. Article 108 states that "All States shall cooperate in the suppression of illicit traffic in narcotic drugs and psychotropic substances engaged in by ships on the high seas. Contrary to international conventions." Based on this article, the state is given the obligation to crush and arrest perpetrators who carry out illicit trade in narcotic drugs and psychotropic substances which are opposed by international conventions. Furthermore, in paragraph 2 it says Any State which has reasonable grounds for believing that a ship flying its flag is engaged in illicit traffic in narcotic drugs or psychotropic substances may request the cooperation of other States to suppress such traffic.

So every country that has suspicions that a ship sailing on the high seas is trading narcotics and psychotropic substances can request assistance from other countries to suppress the trade, other countries are also obliged to cooperate. Article 109 regulates the prohibition of illicit broadcasting from the high seas. Likewise with slavery and piracy in terms of illicit broadcasting on the high seas, countries are also asked to cooperate in eradicating such illicit broadcasting. Article 109 paragraph 2 explains the meaning of illicit broadcasting, namely the transmission of sound radio or television broadcasts from a ship or installation on the high seas intended for reception by the general public Contrary to international regulations, but excluding the transmission of distress calls ${ }^{14}$. So what is meant by illicit broadcasting is any transmission or broadcast broadcast from aboard a ship or other installation on the high seas which is broadcast with the aim of being heard or watched by the general public in contravention of international regulations. Article 111 regulates hot persuit is an exception to the fourth freedom on the high seas. This immediate pursuit is regulated in one article only but is a long article with 8 paragraphs in it. The pursuit of a foreign ship suspected of violating the territory of the coastal state must begin immediately when the ship is in inland waters or island waters. It can only be continued up to the additional zone and territorial sea if the pursuit is not interrupted ${ }^{15}$ :

- The immediate pursuit of a foreign ship may be carried out if the competent authorities of the coastal State have sufficient reason to think that the ship has violated the laws and regulations of that State. Such pursuit must begin when a foreign ship or one of its lifeboats is in inland waters, archipelagic waters, territorial sea or additional zone of the pursuing state, and may only continue outside the territorial sea or additional zone if the pursuit is not interrupted. It is not necessary

\footnotetext{
14 Ibid.

${ }^{15}$ Muhammet Ebuzer Ersoy. INTERNATIONAL LAW OF SEA PIRACY. Vol 3, No 2 (2019) > Ersoy. http://Ippmunissula.com/jurnal.unissula.ac.id/index.php/lawreconstruction/article/view/7791
} 
that when a foreign ship in the territorial sea or an additional zone receives an order to stop, the ship giving the order is also in the territorial sea or an additional zone. If the foreign ship is in an additional zone, as defined in article 33,

- The right of immediate pursuit shall apply, mutatis mutandis to offenses in the exclusive economic zone or on the continental shelf, including safety zones around installations on the continental shelf, to the laws and regulations of the coastal State applicable in accordance with this Convention to the economic zone exclusive or continental shelf, including such safety zones.

- The right of pursuit ceases as soon as the ship being pursued enters the territorial sea of its own State or a third State.

- An immediate pursuit shall not be deemed to have commenced unless the pursuing vessel has satisfied itself, by such practical means as may be available, that the vessel being pursued or one of her lifeboats or other vessels cooperating as a team and using the vessel being pursued as an aircraft carrier is within the boundaries of the territorial sea or as the case may be, within the contiguous zone or exclusive economic zone or on the continental shelf. The pursuit may only begin after being given a visual or audible signal to stop at a distance which allows the sign to be seen or heard by the foreign vessel.

- The right of immediate pursuit can be exercised only by warships or military aircraft or other ships or aircraft that are clearly marked and can be identified as ships or aircraft in government service and are authorized to carry out the task.

- In the case of an immediate pursuit by an aircraft: (a) the provisions of paragraphs 1 and 4 shall apply mutatis mutandis; (b) the aircraft giving the order to stop must pursue the ship actively until the ship or aircraft of the coastal State summoned by the pursuing aircraft arrives to take over the pursuit, unless the aircraft itself is able to make arrests of the ship. It is not sufficient to justify an arrest outside the territorial sea that the ship is only visible to the aircraft as a trespasser or suspected violator, if the ship is not ordered to stop and is pursued by the aircraft itself or by other aircraft or other ships proceeding the pursuit was uninterrupted.

- The release of a ship detained in the jurisdiction of a State and escorted to a port of that State for the purpose of inspection before the competent authorities shall not be prosecuted solely on the grounds that the ship, in its voyage, is escorted through a part of the exclusive economic zone or the high seas if circumstances require it.

- In the event that a ship has been stopped or detained outside the territorial sea in circumstances that do not justify the exercise of the right of immediate pursuit, then the ship must be compensated for any loss and damage that has been suffered because of it, pollution of the marine environment. Marine pollution is a change in the marine environment that occurs as a result of the direct or indirect introduction of materials or energy by humans into the marine environment (including river mouths) that results in such adverse effects as to constitute a loss to biological wealth, a hazard to human health, disturbance to activities at sea including fishing and other reasonable use of the sea, deterioration of the quality of sea water and the decline in places of settlement and recreation. The high seas have become the open sea and every country has the right to be able to take advantage of the high seas. Apart from being a means of transportation and a place of research, the high 
seas can also be used as a place to catch fish for food. So as human beings we are obliged to maintain and preserve the marine environment.

\section{Closing}

The regulation regarding the high seas is contained in Part VII Articles 86 to 120 of the 1982 Law of the Sea Convention. Every country is given the right and freedom to use the high seas. State freedoms on the high seas are freedoms in accordance with article 87, namely freedom of navigation, flight, laying submarine cables and pipelines, freedom to build artificial islands and other installations, freedom to fish, and freedom to conduct scientific research. The benefits given can be used by every country but every country is obliged to maintain and utilize the high seas for peaceful purposes for the survival of human life. In addition to providing freedom to use the high seas, the 1982 Law of the Sea Convention provides exceptions to this freedom. Where every country is free to use the high seas but is not allowed to take illegal actions or violate the law, both national law and international law which in its application is often violated by countries in the world. There are several exceptions to the freedom of the high seas such as the prohibition of slavery, piracy), trafficking in narcotic drugs and psychotropic substances, real-time pursuit, illicit broadcasting, and pollution of the marine environment. So every country, both coastal and non-coastal countries, is required to cooperate in eradicating all forms of abuse of freedom on the high seas. There are several exceptions to the freedom of the high seas, such as the prohibition of slavery, piracy, trafficking in narcotic drugs and psychotropic substances, direct pursuit, illicit broadcasting, and pollution of the marine environment. So every country, both coastal and non-coastal countries, is required to cooperate in eradicating all forms of abuse of freedom on the high seas.

\section{References}

\section{Journal:}

[1] Anirut Chuasanga, Ong Argo Victoria. ISM-CODE AS A LEGAL PROTECTION OF USE SHIPS ARE NOT CONFORT WITH MARINE STANDARD IN INDONESIA. Vol 8, No 1 (2021) $>$ http://Ippmunissula.com/jurnal.unissula.ac.id/index.php/PH/article/view/15265

[2] Buchari, E., \& Victoria, A. (2021). Policies Conducted to Support Maritime Safety and Security in Sea Transportation Systems. KnE Social Sciences, 5(1), 238-248. https://doi.org/10.18502/kss.v5i1.8286

[3] Hartanto, H.; Victoria, O.A.; Chuasanga, A. Maritime Transportation in Indonesian Policy. J. Pembaharuan Huk. 2019, 6, 36-44, Jurnal Pembaharuan Hukum Unissula, Vol. 6, No. 1 (2019), http://jurnal.unissula.ac.id/index.php/PH/article/view/4657

[4] Junyu, M., Victoria, O. A., \& Arifani, D. (2021). Sea Transportation System Policy. KnE Social Sciences, 5(1), 147-157. https://doi.org/10.18502/kss.v5i1.8277

[5] Muhammet Ebuzer Ersoy. INTERNATIONAL LAW OF SEA PIRACY. Vol 3, No 2 (2019) $>\quad$ Ersoy. $\quad \underline{\text { http://lppm- }}$ unissula.com/jurnal.unissula.ac.id/index.php/lawreconstruction/article/view/779 $\underline{1}$ 
[6] Paulina M. Latuheru, Miko Priambudi \& Ong Argo Victoria. Responsibility of Sea Transportation Services. VOL 2 NO 1 (2020): INTERNATIONAL WATER TRANSPORT JOURNAL (IWTJ: OCTOBER) / Articles- http://ejournal.poltektranssdppalembang.ac.id/index.php/IWTJ/article/view/84

[7] Shatat Saleh Raed Shatat. INTERNATIONAL LAW INTERNATIONS AND HUMAN RIGHTS. Vol 6, No 2 (2019) > http://lppmunissula.com/jurnal.unissula.ac.id/index.php/PH/article/view/274-284

\section{Books:}

[1] Admiralty and Maritime Law Bibliography: Access to the Sea: LibGuide from the University of Richmond Law Library

[2] Elsevier's Maritime Dictionary in Three Languages, English, French, and Arabic: Call Number: KB 146 B16

[3] Marine Affairs Bibliography: A Comprehensive Index to Marine Law and Policy Literature: Call Number: JX 4411 W66

[4] Marine Encyclopaedic Dictionary by Eric Sullivan: Call Number: KB 148 .S22 S94 1999

[5] The Law of the Sea: A Select Bibliography: Call Number: JX 4411 L418

[6] Transports maritimes: termes techniques, juridiques, et commerciaux: lexique anglais-français: Call Number: K 13. .F8 T77

[7] United Nations. Division for Ocean Affairs and the Law of the Sea. The Law of the Sea: multilateral treaties: a reference guide to multilateral treaties and other international instruments related to the United Nations Conventions on the Law of the Sea (revised and updated as of 31 December 1996). Edition: Law of the sea/Maritime law -- Indexes (United Nations publication sales no. E.85.V.12 [i.e. E.85.V.11])"--P. x. "United Nations publication sales no. E.97.V.9"--T.p. verso. Publisher New York: United Nations, 1997, Format: xiii, 184 p. ; 28 cm., ISBN : 9211335213 (pbk.) 